\title{
Pesan Dakwah dalam Program Televisi Muslim Travelers NET.
}

\author{
Muhammad Deni Wijaya*, Siti Sumijaty, Uwes Fatoni \\ Jurusan Komunikasi dan Penyiaran Islam, Fakultas Dakwah dan Komunikasi, \\ UIN Sunan Gunung Djati, Bandung \\ *Email: deniwijaya213@gmail.com
}

\begin{abstract}
This research discusses the da'wah messages that exist in the Muslim Traveler NET television program. the messages conveyed are adapted to media functions that are informative, persuasive and entertaining. The method used in this study is a qualitative content analysis using a coding sheet, then analyzed together with the resulting data collection made in a descriptive qualitative form. The results of this study found 31 da'wah messages that fit the categories in the study, namely 15 informative da'wah messages, 13 persuasive da'wah messages and 3 entertainment da'wah messages from 5 episodes of Muslim travelers airing in 2018 namely 3 South Korean episodes, 1 South American episode and 1 episode of Spain. informative da'wah messages that discuss a lot about the arrival of Islam, Islamic symbols and information about halal food, persuasive da'wah messages motivate and encouragement to uphold Islamic Shari'a, worship also da'wah and the last, entertainment da'wah message of that displays culture, panorama and artwork.
\end{abstract}

Keywords : da'wah messages; television programs; NET

\begin{abstract}
ABSTRAK
Penelitian ini membahas tentang pesan dakwah yang ada pada program televisi muslim travelers NET. pesan yang dibahas disesuaikan dengan fungsi media yaitu informatif, persuasif dan hiburan. Metode yang digunakan dalam penelitian ini ialah analisis isi kualitatif dengan menggunakan coding sheet, lalu dianalisis bersamaan dengan pengumpulan data yang hasilnya dibuat dalam bentuk deskriptif kualitatif. Hasil dari penelitian ini ditemukan 31 pesan dakwah yang sesuai dengan kategori dalam penelitian, yaitu 15 pesan dakwah informatif, 13 pesan dakwah persuasif dan 3 pesan dakwah hiburan dari 5 episode muslim travelers yang ditayangkan tahun 2018 yaitu 3 episode Korea Selatan, 1 episode Amerika dan 1 episode Spanyol. Pesan dakwah informatif banyak membahas tentang kedatangan Islam, syiar Islam dan informasi tentang makanan halal, pesan dakwah persuasif meliputi ajakan dan motivasi untuk menegakan syariat Islam, beribadah juga berdakwah dan pesan dakwah hiburan yang menampilkan pemandangan, kebudayaan alam dan karya seni.
\end{abstract}

Kata Kunci : pesan dakwah; program televisi; NET. 


\section{PENDAHULUAN}

Dakwah di zaman kontemporer ini tidak terlepas dari pengaruh teknologi, media dan masyarakat yang semakin maju baik dari segi ekonomi, sosial dan juga pendidikannya. Berkembangnya masyarakat dan media berpengaruh juga terhadap kegiatan berdakwah, saat ini dakwah tidak hanya sebatas ceramah di majelis taklim saja, banyak cara dan media yang bisa digunakan dalam berdakwah.

Televisi salah satu media yang mudah dijumpai selain harganya yang relatif murah, televisi juga mudah diakses karenanya televisi dekat dengan kehidupan masyarakat sehari-hari, televisi juga bisa menjadi media yang digunakan untuk berdakwah. Peran media terutama televisi bisa menjadi alternatif untuk menyebarkan pesan dakwah melalui program-programnya (Japarudin, 2012: 2).

Pesan dakwah yang disampaikan bisa berupa pesan dakwah akhlak, aqidah dan syariah yang mana pesan-pesan tersebut bersumber dari Alquran dan Hadis. Agar pesan dakwah tidak mononton maka perlu dikemas semenarik mungkin agar dapat dengan mudah diterima oleh masyarakat melalui program televisi.

Saat ini banyak stasiun televisi yang berlomba-lomba membuat program untuk menarik penonton. Semakin bagus programnya dan banyak diminati maka semakin besar pula pengaruhnya terhadap masyarakat, juga menambah rating pada program tersebut.

Banyak program yang bisa disaksikan di televisi salah satunya programprogram yang bernuansa Islam, dari mulai news, sinetron, variety show bahkan acara yang memang khusus ceramah. misalnya seperti Berita Islami Masa Kini TransTV, Khazanah Trans7, Para Pencari Tuhan SCTV, Saliha NET, Damai Indonesiaku TVOne, dan dari sinilah banyak pula bermunculan Dai-dai populer karena mereka memanfaatkan media massa khususnya televisi untuk menyebarkan ajaran Islam melalui tayangan atau program-program televisi.

Salah satu program bernuansa Islam yang ada di NET. atau News and Entertainment Television adalah Muslim Travelers, program ini adalah program andalan NET. di bulan ramadhan dengan konsep dokumenter, reality show, hiburan dan petualangan, yang ditayangkan setiap hari pukul 04.30 selama bulan ramadhan.

Program ini dimulai sejak tahun 2014 di dalam setiap episodenya program muslim travelers membahas tentang bagaimana Islam bisa berkembang, bagaimana syiar Islam dan juga bagaimana kehidupan muslim di negara-negara yang mayoritas non muslim sekaligus suka duka mereka di negeri tersebut. muslim travelers juga menjelaskan bagaimana negara-negara mayoritas non muslim mulai memahami Islam.

Seperti di episode Korea Selatan, muslim travelers menjumpai warga lokal yang menjadi muslim dan membuka restoran halal yang dikhususkan untuk warga muslim, lalu ada warga negara asing yang merupakan muslim dan membuka penginapan khusus muslim tetapi diminati pula oleh non muslim. 
Muslim travelers juga mendatangi masjid-masjid yang ada di Korea Selatan untuk mengulik bagaimana sejarah Islam dan syiar Islam disana dan bertemu dengan muslim-muslim dari Indonesia.

Pada episode yang lain yaitu di Amerika, muslim travelers juga mendatangi masjid yang ada di Amerika dan bertemu dengan warga lokal yang menjadi mualaf, tidak lupa dengan kisah bagaimana Islam berkembang dan bagaimana muslim dapat beribadah dan mendapat makanan halal terakhir yaitu episode di Spanyol yang mana muslim travelers mendatangi destinasi wisata yang menjadi sejarah peradaban Islam di Spanyol.

Banyak stasiun televisi yang menayangkan program-program bernuansa Islam dengan konsep ceramah, siraman rohani yang disampaikan oleh ustadz dan ustadzah, tetapi dalam program muslim travelers ini pesan dakwah dikemas dengan cara yang lebih menarik dan juga modern, host yang langsung terjun ke lapangan untuk melakukan wisata religi menjadikan program televisi ini menarik untuk di teliti.

Bagian ini menjelaskan tentang konsep yang berkaitan dengan penelitian, yaitu tentang dakwah, pesan dakwah, televisi beserta programnya. Dakwah ialah aktivitas keislaman dimana da'i memberikan motivasi, contoh kesadaran yang baik, melalui aktivitas lisan, tulisan ataupun aktivitas perbuatan untuk merealisasikan ajaran-ajaran Islam yang nantinya dikerjakan oleh setiap muslim dengan kemampuannya masing-masing untuk mencapai ridha Allah (Aliyudin, dkk, 2009: 52-53). Adapun pengertian dakwah menurut bebErapa tokoh dalam buku ilmu dakwah (Aziz, 2009: 11-19) yang dapat dikategorikan sebagai berikut (1) dakwah dari sisi psikologi yaitu mengajak orang-orang untuk meyakini dan mengamalkan aqidah dan syariat Islam (2) dakwah dari sisi sosiologi yaitu dimana da'i mengubah keadaan umat menjadi lebih baik di segala aspek kehidupan (3) dakwah dari sisi antropologi yaitu mengajak orang-orang untuk memeluk agama Islam dan mengamalkan ajarannya secara konsisten.

Tujuan dakwah menjadi bagian penting dalam proses berdakwah karena tanpa tujuan maka proses dakwah tidak akan bemakna. Tujuan dakwah dapat diartikan mengajak umat manusia baik muslim maupun non muslim untuk ke jalan yang di ridhai Allah (Munir, dkk, 2009: 88).

Pada zaman modern saat ini dakwah tidak hanya dilakukan oleh perorangan saja melainkan bisa dilakukan oleh suatu lembaga, karena pengaruh dari teknologi dan perubahan sosial maka tantangan dalam berdakwah tidak bisa ditanggulangi oleh perorangan, untuk mencapai tujuan dakwah maka dakwah yang dilakukan kolektif oleh suatu lembaga sangat diperlukan (El Ishaq, 2016: 54-57).

Selanjutnya melalui kelembagaan, kegiatan berdakwah dapat dirinci dan nantinya memudahkan untuk memilih tenaga kerja yang diperlukan untuk melaksanakan kegiatan berdakwah, serta alat-alat yang dibutuhkan. Selain memudahkan kegiatan dakwah yang dilakukan dengan kelembagaan juga akan mendatangkan keuntungan yaitu berkumpulnya keahlian-keahlian dari para 
pelaksana dakwah yang nantinya akan bekerjasama dimana semuanya diarahkan pada sasaran yang sebelumnya telah ditentukan (Amin, 2013:134). Adapun unsur-unsur dalam dakwah seperti subjek dakwah, objek dakwah, materi dakwah, metode dan media dakwah.

Pesan dakwah atau materi dakwah merupakan salah satu bagian terpenting dari proses dakwah yang mana isinya merupakan ajaran Islam yang disampaikan oleh da'i kepada mad'u. pesan dakwah juga bisa diartikan sebagai pelajaran tetang agama yang disampaikan oleh da'i kepada mad'u untuk mencapai tujuan yang telah ditentukan. Pesan dakwah dapat berupa aqidah, syariah dan ahlak semua materi tersebut bersumber dari Alquran, Hadis, hasil ijtihad para ulama juga sejarah peradaban Islam (Saputra, 2011: 8).

Pesan dakwah yang disampaikan da'i harus mampu merubah keadaan mad'u dan mendorongnya untuk mau mengamalkannya. Pesan dakwah disampaikan untuk mempengaruhi mad'u yang mana mampu menyentuh kesadaran dan mendorong mad'u agar bersikap dan berperilaku seperti pesan yang disampaikan oleh da'i (Fatoni, dkk, 2017: 210). Pada dasarnya selama pesan dakwah tidak bertentangan dengan Alquran dan Hadis maka pesan dakwah bisa disampaikan kepada mad'u untuk diamalkan.

Terdapat sembilan jenis pesan dakwah dalam buku ilmu dakwah (Aziz, 2009: 319-330), (1) Ayat Quran, pesan ini berasal ayat-ayat quran yang dijelaskan secara umum dan dijelaskan lebih detailnya oleh hadis (2) Hadis Nabi pesan ini berasal dari perkataan dan perbuatan Nabi Muhammad Saw (3) Pendapat para sahabat Nabi, mereka yang hidup pada masa nabi, mengenal dan beriman kepada nabi Muhammad (4) Pendapat para ulama, mereka adalah orang-orang yang beriman, menguasai ilmu keislaman secara mendalam dan mengamalkannya (5) Hasil penelitian ilmiah, beberapa ayat quran dapat dipahami melalui hasil penelitian, meski nilai kebenarannya relatif karena bisa berubah oleh penelitianpenelitian selanjutnya (6) Kisah dan pengalaman teladan, pesan ini bisa dengan menceritakan pengalaman seseorang atau pribadi. Bahkan bisa bercerita tentang riwayat nabi yang mana didalam akhlaknya banyak petunjuk kebenaran (Zahrah, 1994: 76). (7) berita dan peristiwa, dalam hal ini berita dan peristiwa yang benar saja yang bisa dijadikan sebagai pesan dakwah (8) karya sastra, terkadang pesan dakwah perlu di dukung oleh karya sastra yang bernilai tinggi seperti syair atau puisi, karya sastra berkembang mengikuti zaman karenanya bahasa yang digunakan mudah diterima masyarakat, sama halnya dengan pesan dakwah yang disampaikan melalui karya sastra akan mudah juga untuk diterima (Yolanda, 2017: 458) terakhir (9) karya seni, karya seni mnegacu pada komunikasi nonverbal yang mengacu pada lambang juga mudah ditafsirkan oleh siapapun, tidak semua karya sastra bisa dijadikan pesan dakwah hanya beberapa yang memiliki kriteria berikut, tidak berlebihan agar tidak salah tafsir, tidak menjadikan mahkluk hidup sebagai objek dan tidak mengandung unsur pornografi. 
Pesan dakwah tersebut bisa bersifat informatif artinya pesan dakwah dapat memberikan informasi dan penerangan, selanjutnya bersifat persuasif artinya pesan dakwah harus dapat memberikan pengaruh dan terakhir pesan dakwah bersifat hiburan artinya pesan dakwah tersebut menarik dan menyenangkan bagi si penerimanya.

Dalam proses dakwah ada unsur yang juga sama pentingnya dengan materi atau pesan dakwah yaitu media dakwah. Media dakwah ialah perantara seorang da'i untuk menyampaikan pesan dakwahnya kepada mad'u. Saat ini dakwah telah berkembang baik metodenya maupun media yang digunakannya dimana mengikuti perubahan zaman, media yang mudah diakses dan dekat dengan kehidupan sehari-hari masyarakat ialah televisi.

Televisi menjadi media yang praktis, mudah, dan harganya terjangkau, juga cepat dalam menyajikan pesan dan menyebarluaskan pesan-pesannya. Selain itu televisi dapat memberikan hiburan sekaligus pengetahuan, khususnya pengetahuan di bidang keagamaan, sehingga akan ada peningkatan dari sisi pemahaman, pengamalan, dan penyebaran nilai-nilai keagamaan di masyarakat. Saat ini banyak televisi yang secara langsung ataupun tidak, program dan tayangannya membawa misi dalam menyebarkan dan menanamkan nilai-nilai Islam dalam kehidupan masyarakat, dalam hal ini televisi sudah bernafaskan Islam (Dulwahab, 2016: 2).

Era televisi di Indonesia dimulai pada tanggal 17 Agustus 1962 saat itu stasiun TVRI melakukan percobaan siarannya dengan meliput upacara peringatan Hari Proklamasi di Istana Negara, lalu memulai siaran secara kontinu pada tanggal 24 Agustus 1962. Pada tahun 1989 di mulainya era televisi swasta di Indonesia dengan hadirnya RCTI lalu diikuti dengan stasiun televisi swasta lainnya seperti TPI atau yang sekarang dikenal dengan MNC, SCTV, Indosiar, Metro Tv, Trans Tv, TVOne dan lainnya. Selain TV swasta nasional, banyak juga televisi lokal dan komunitas yang tersebar di seluruh nusantara (Vera, 2016: 80).

Program televisi ialah salah satu bagian dari televisi yang tidak bisa dipisahkan, program televisi merupakan segala sesuatu yang ditampilkan atau disiarkan oleh televisi untuk memenuhi kebutuhan penonton. Adapun jenisjenis program televisi yang dibagi kedalam dua jenis, (1) program informasi yang meliputi, hard news dan soft news (2) program hiburan meliputi drama, musik, games, dan pertunjukan (Vera, 2016: 82-84).

Televisi sebagai alat komunikasi massa memiliki empat fungsi yang meliputi fungsi to inform, to educate, to entertain dan to influence. Fungsi to inform artinya televisi sebagai penyampai berita, peristiwa atau gagasan yang bersifat actual (baru) yang bisa memberikan pemahaman baru dan wawasan yang luas, fungsi to educate artinya apa yang diampaikannya dapat menambah pengembangan intelektual, pembentukan watak, penambahan keterampilan dan mampu memecahkan masalah di kalangan masyarakat, fungsi to entertain televisi bisa memberikan hiburan, menghilangkan ketegangan, penat dan lebih santai dan fungsi to influnce 
yaitu televisi mampu mempengaruhi pendapat, pikiran bahkan perilaku masyarakat, bahkan media yang memiliki kemandirian (independent) akan mampu bersuara atau berpendapat dan bebas melakukan pengawasan sosial (Afdjani, 2014: 156-157).

Dakwah di zaman modern saat ini harus dibuat lebih dinamis, progresif dan penuh inovasi. Dimanapun, kapanpun dan dengan cara apapun masyarakat bisa mendapatkan pengetahun tentang ajaran-ajaran Islam, masyarakat bisa memanfaatkan media seperti buku, majalah, internet, radio dan televisi (Basit, 2013: 77-78).

Pemanfaatan televisi sebagai media dakwah telah banyak dilakukan oleh beberapa stasiun televisi baik pemerintah maupun swasta, itu dibuktikan dengan adanya program-program acara yang bernuansa Islam. Meski begitu televisi juga bisa menjadi alat propaganda dan mempengaruhi sikap juga opini publik dengan acara yang disiarkannya karena pengaruhnya yang cukup signifikan terhadap orang yang menontonnya (Japarudin, 2012: 12-13).

Program-program bernuansa Islam juga memberikan dampak dimana munculnya mubaligh pop, yang dimaksud mubaligh pop adalah mubaligh yang menggunakan media-media budaya populer dalam menyebarkan ajaran-ajaran Islam. Masuknya mubaligh pada ranah media pop awalnya sangat disayangkan karena media pop memiliki budaya yang berbeda dengan nilai-nilai yang disusung oleh seorang mubaligh, karena media pop lebih berorientasi pada bisnis utama hiburan dan informasi, sedangkan mubaligh memiliki upaya untuk menanamkan nilai-nilai etika dan moral agama (Farihah, 2013: 35-36). Mubaligh yang tampil di televisi khususnya dalam program Islami tidak hanya dianggap sebagai sosok panutan dalam beragama tetapi juga berperan sebagai ikon budaya ajaran Islam pada masyarakat (Rustandi, 2018: 212).

Adapun keunggulan televisi sebagai media dakwah yaitu (1) dekat dan tidak lepas dari kehidupan masyarakat, kontens-kontens yang dikembangkannya menjadi suatu kultur publik yang berbeda dari yang ada sebelumnya, (2) sebagai media dengar pandang (audio visual) keunggulan televisi ada pada daya persuasinya yang tinggi, karena penonton dapat melihat gambar hidup dan suara sekaligus. Televisi juga dapat menyiarkan peristiwa yang sedang terjadi dan penonton dapat dengan langsung melihatnya melalui layar televisi. Dengan demikian televisi memiliki kecepatan, aktualitas dan daya persuasi yang tinggi, (3) televisi memiliki daya jangkau (coverage) yang luas dalam menyebarkan pesan dengan cepat, dimana dampaknya terasa dalam kehidupan individu dan masyarakat. Itu pula yang disebut "Desa Global" oleh Mc Luhan dalam teori ekologi media dimana media seolah mengikat penggunanya dan dampaknya bisa dirasakan secara bersama-sama pula (Zaini, 2015: 12).

Dari keunggukan yang telah disebutkan diatas, televisi bisa menjadi media dakwah yang efektif. Televisi menjadi media dakwah yang efisien dan menarik untuk pengembangan dakwah. adapun fungsi televisi adalah sebagai media penyampai informasi, hiburan, pendidikan, dan sebagainya (Zaini, 2017: 222). 
Agar dakwah televisi bisa diterima dan diminati oleh mad'u maka dakwah harus dikemas dengan semenarik mungkin dan bisa mengena ke mad'u di berbagai bidang. Program dakwah juga harus tampil aktual (bisa memecahkan masalah yang tengah terjadi di masyarakat), faktual (kongkrit dan nyata), dan terakhir kontekstual (relevan yang berhubungan dengan problema yang sedang terjadi di masyarakat). Oleh karenanya memilih metode dan media yang tepat dalam berdakwah menjadi bagian yang penting untuk menyajikan dakwah yang menarik dan menggugah penonton televisi (Atabik, 2013: 197).

Program Islami di televisi harus dikemas semenarik mungkin agar bisa menghibur namun tetap memberikan informasi dan edukasi di dalamnya. Program Islami di televisi harus memenuhi fungsi mendidik juga menghibur, kedua aspek tersebut pada intinya disesuaikan dengan budaya masyarakat modern saat ini (masyarakat yang haus akan informasi juga penat dengan segala rutinitas yang membebaninya) (Rustandi, 2018: 211).

Pengetahuan dan kemampuan seorang da'i tentang media dan pengemasan program televisi menjadi sangat penting, terlebih lagi harus pandaipandai mengakali bagaimana pesan disampaikan layaknya tontonan atau hiburan tetapi dapat memberikan inspirasi dan motivasi kepada pengguna media maupun penonton televisi untuk menjalankan pesan-pesan dakwah yang telah disampaikan (Ishaq, 2013: 144). Meski begitu sudah banyak program-program televisi yang bernuansa Islami yang bisa dijumpai di televisi, dari sinetron, variety show, talk show atau bahkan program ceramah atau siraman rohani itu sendiri, dan beberapa acara yang rutin diadakan ketika waktu-waktu tertentu khususnya bulan ramadhan.

Terdapat beberapa penelitian yang relevan dengan penelitian ini, diantaranya: (1) Fatimah Pallawagau (2014) meneliti tentang pesan dakwah pada program Khazanah Trans 7 mencakup pesan dakwah aqidah, syariah dan ahlak dengan metode kuantitatif. (2) Syafrian Akbar (2010) meneliti tentang televisi sebagai media dakwah program Ustad Haryono di JakTV, dengAn menganalisis tahapan produksi mencakup pra produksi, produksi dan psca produksi. (3) Agus Usnaien (2011) meneliti tentang program Kick Andy di Metro TV dengan menganalisis tahapan produksi. Perbedaan penelitian ini dengan penelitian sebelumnya ialah pada objek penelitian dimana dalam penelitian ini menganalisis dakwah informatif, persuasif dan hiburan pada program televisi muslim travelers NET.

Adapun rumusan masalah dalam penelitian ini yaitu bagaimana pesan dakwah informatif, pesan dakwah persuasif dan pesan dakwah hiburan pada program muslim travelers NET. yang ditayangkan tahun 2018 dengan mengambil tiga episode Korea Selatan, satu episode Amerika Serikat dan satu episode Spanyol.

Metode dalam penelitian ini menggunakan metode analisis isi kualitatif dimana dalam proses pengumpulan datanya, melalui tahap coding sheet yang dilakukan oleh dua koder untuk mencari persamaan data yang sesuai dengan 
objek penelitian. Setelah data dikumpulkan, selanjutnya data di analisis dan ditarik kesimpulan sebagai hasil penelitiannya.

\section{HASIL DAN PEMBAHASAN}

Muslim travelers merupakan salah satu program andalan dari NET. program ini hadir khusus di bulan ramadhan dengan durasi 30 menit setiap episodenya. Muslim travelers hadir dengan mengusung konsep gabungan seperti dokumenter, reality show, hiburan dan petualangan. Program ini menceritakan beragam kisah dari kehidupan muslim di seluruh dunia, seperti bagaimana menjalani hidup di negara mayoritas non muslim, bagaimana mereka beradaptasi dan melawan stigma buruk dari orang-orang luar juga bagaimana syiar Islam di negara-negara yang mayoritas non muslim. Muslim travelers tayang sejak tahun 2014 setiap hari selama bulan ramadhan jam 04.30.

Program muslim travelers NET. dipandu oleh beberapa host seperti Gita Savitri Devi, Hamidah Rachmayanti, Shaza Belladona, Chiki Fawzi, Wilman Latief, Firza Arifien dan Muthia Amalia, beberapa diantaranya pernah mendapatkan penghargaan sebagai Host Muda Inspiratif dari Komisi Penyiaran Indonesia, seperti Gita Savitri Devi tahun 2018, dan baru-baru ini Muthia Amalia juga mendapatkan penghargaan sebagai Host Muda Inspiratif 2019 dari Komisi Penyiaran Indonesia. Muslim Travelers juga pernah mendapatkan penghargaan sebagai program ramadhan terbaik dari Komisi Penyiaran Indonesia (KPI) dan Majelis Ulama Indonesia (MUI) pada tahun 2014 dan di tahun 2019 Muslim Travelers kembali mendapatkan penghargaan dalam kategori Spesial Syariah Halal Life Style.

Dalam program muslim travelers NET. yang ditayangkan tahun 2018 peneliti memilih satu episode Amerika Serikat, satu episode Spanyol dan tiga episode Korea Selatan. Setelah melalui coding sheet peneliti menemukan 31 pesan dakwah yang sesuai dengan rumusan masalah pesan dakwah informatif, pesan dakwah persuasif dan pesan dakwah hiburan.

\section{Pesan Dakwah Informatif}

Pesan dakwah informatif adalah pesan dakwah yang mana isi dari pesan tersebut bisa memberikan wawasan dan pengetahuan juga informasi khususnya tentang ke-Islaman. Dakwah sebagai gerakan informatif adalah kegiatan yang sifatnya memberikan pengetahuan, pemahaman ke-Islaman baik individu atau kelompok dalam hal ini ialah masyarakat (Badaruddin, 2013 : 53).

Ditemukan 15 Pesan dakwah informatif dalam program televisi muslim travelers NET. yang membahas tentang kedatangan Islam, syiar Islam dan informasi tentang makanan halal.

Pertama pesan dakwah informatif tentang kedatangan Islam pada program muslim travelers NET. salah satunya ada di episode Spanyol, yaitu saat host Chiki Fawzi berkunjung ke Istana La-Alhambra di Granada, berikut contohnya: 
“...Peninggalan budaya Islam/ berupa istana sekaligus benteng pertahanan terakhir muslim/ di Spanyol/ Alhambra//.... Alhambra/ adalah saksi bisu keruntuhan Islam di bumi Andalusia/ nama Alhambra sendiri/ diambil dari bahasa Arab/ "Ahmar"/ yang artinya merah/... Islam masuk Spanyol tahun 711/ Islam di spanyol kemudian mencapai puncak kejayaan/ pada era 900 Masehi/ jatuhnya kota Granada/ sekaligus jadi penanda akhir kebesaran panji-panji ini//.... Alhambra berdiri tahun 1238/ atau udah lebih dari 780 tahun yang lalu//,.... De Quarto de Mortals misalnya/ area ini merupakan refleksi dunia dan akhirat/ maknanya jadi semacam pesan/ bahwa segala apa yang kita lakukan di dunia/ merupakan cerminan akan apa yang kita dapat di akhirat nanti//...Kaligrafi dan Asmaul Husna/ mengelilingi keindahan kawasan Alhambra ini/ dan salah satu yang bikin saya takjub/ adalah ada jendela kecil di tengah/ itu adalah tempat istirahat sultan/ yang di sekeliling jendelanya itu/ dikelilingi ayat kursi yang diukir di sekitarnya/ tujuannya adalah/ untuk mengingatkan lagi seisi istana bahwa/ hasbunallah wanikmal wakil kita harus selalu cukup hidup hanya dengan Allah//..." (25 Mei 2018, 02:38-06:35).

Dari kalimat tersebut kita dapat mengetahui sejarah Islam dan peninggalannya di Spanyol yaitu istana Alhambra, seperti yang kita ketahui bahwa Islam pernah berjaya di Spanyol, yang mana istana Alhambra sendiri merupakan bagian dari kerajaan Granada yaitu kerajaan terakhir umat muslim di Spanyol yang kalah dan jatuh ke tangan pemerintahan Kristen pada tahun 1492 M (Firdaus, 2009: 249).

Pesan dakwah ini menjadi pesan dakwah informatif karena selain menambah wawasan tentang Islam kita juga bisa mentadaburinya, ditambah lagi dengan kalimat yang berisikan bahwasanya tujuan diukirnya ayat kursi di sekeliling jendela istana adalah untuk mengingatkan bahwasanya hasbunallah wanikmal wakil yang mana kalimat tersebut ialah potongan dari salah satu dzikir yakni Hasbunallah Wanikmal Wakil Nikmal Maula Wanikman Nasir. Yang mana dzikir sendiri memiliki keutamaan yaitu amalan yang disukai Allah, menjaga hati, penenang dan penentram hati juga menambah rezeki dan membuat hidup nyaman (Basri, 2014: 27-35). Pentingnya pesan dakwah informatif diatas untuk menambah pengetahun dan wawasan tentang Islam juga rasa syukur kita kepada Allah.

Kedua pesan dakwah informatif tentang syiar Islam pada program muslim travelers NET. ada di Episode Korea Selatan (Islam di Korea Selatan) saat itu, Shaza Belladona sebagai pembawa acara, berkunjung ke hotel FN House yang berada di Seoul yang mana pemiliknya seorang muslim dari Malaysia, berikut contohnya:

"Shaza: kenapa FN House ini di branding jadi Muslim Guest House kenapa nggak general gitu? Nasihah : firstly/ kami itu muslimkan,/ saya dan juga husband/ and I think is plus point/ because people in korea ni 
sangat sukar, muslim is not norm/ So itu satu benda yang susah dibuatkan/ jadi we believe that if use kind of point/ muslim/ focus / ramai lagi tuh/ ramai lagi yang akan datang/ plus kami udah tahukan market/ mostly yang kesini ramainya Southeast Asian/ ramainya muslim juga/ So if you can see even korea ready no halal industry/ ramai juga membuahkan industry. So why no we just continue as muslim/ lagipun orang non muslim juga suka, suka yang konsep muslim/bersih gitukan//" (05 Juni 2018, 18:13-19:10).

Dari kalimat diatas menginformasikan tentang tempat tinggal bagi muslim, juga pemilik penginapan yang secara tidak langsung memperkenalkan Islam dan membantu memudahkan orang-orang muslim. Baik disengaja atau tidak pemilik mengenalkan Islam melalui konsep penginapan yang bersih dan ternyata disukai oleh non muslim juga, sama halnya dengan berdakwah pemilik penginapan ini juga berdakwah melalui caranya sendiri yaitu dengan membuat penginapan.

Dakwah dengan pendekatan ekonomi memang belum sepenuhnya terlaksana namun sudah ada beberapa yang melakukannya misalnya dengan mendirikan yayasan-yayasan meski memang belum maksimal (Zulkarnaini, 2015: 157). Dari pesan dakwah informatif diatas dapat diketahui bahwa Islam dapat dikenalkan dan disebarluaskan melalui banyak cara salah satunya dengan mendirikan sebuah penginapan dengan konsep yang Islami.

Ketiga pesan dakwah tentang infromasi makanan halal ada di episode Korea Selatan (Gangnam), sang pembawa acara yaitu Shaza Belladona bertemu dengan Ayana Moon seorang mualaf di Coex Mall lalu mereka berbincang-bincang, Ayana menceritakan bagaimana ia masuk Islam dan apa yang dirasakan setelah menjadi muslim, dan berbagi informasi tentang makanan halal di Korea Selatan, berikut contohnya:

“...Seiring dengan berkembangnya Islam/ penyedia produk pangan halal di Seoul juga makin banyak// Namun/ tetap ada tantangan bagi muslim dan muslimah/ dalam menunaikan ibadah/ di negara dimana Islam bukan agama mayoritas/ diantaranya ketika berpuasa//" (18 Mei 2018, 10:45 11:04).

Saat narasi tersebut, ditunjukan salah satu tempat yang menyediakan makanan halal di Korea Selatan tepatnya di Distrik Gangnam, yaitu Coex Mall. Dari situ, terlihat jelas bahwa penonton bisa mendapatkan informasi mengenai makanan halal yang ada di Korea Selatan juga diingatkan kembali bahwa penting sekali untuk muslim mengkonsumsi makanan yang halal. Seperti firman Allah dalam surat Al-Maidah (5) : 88 :

"Dan makanlah dari apa yang telah diberikan Allah kepadamu sebagai rezeki yang halal dan baik, dan bertaqwalah kepada Allah yang kamu beriman kepadanya" (Kemenag RI, 2006 : 162).

Dalam tafsir Kementerian Agama RI menjelaskan, "dan makanlah oleh kamu wahai orang-orag yang beriman, dari apa yang telah diberikan Allah kepadamu, berupa bahan makanan yang berasal dari darat maupun dari laut. 
Baik protein nabati maupun protein hewani sebagai rezeki yang halal dan baik untuk menopang aktivitas kamu dalam hidup dan kehidupan ini; dan bertaqwalah kepada Allah dengan melaksanakan perintahnya dan menjauhi larangan-Nya, yang kepada-Nya kamu beriman dengan ikhlas dan istiqamah".

Kata "halal" disini ialah halal barang dan cara memperolehnya, dan kata "baik" dari manfaatnya yang mana terdapat vitamin, protein, gizi dan lainnya. Makanan halal dalam Islam bisa dilihat dari beberapa faktor seperti, bahan makanan, peralatan dan cara memasak juga menyembelih jika makanan tersebut berasal dari binatang. Makanan halal yang berasal dari tumbuhan sangat jarang diragukan kehalalannya, berbeda halnya dengan makanan yang berasal dari binatang, makanan yang berasal dari binatang perlu diragukan kehalalannya karena tergantung bagaimana cara penyembelihannya, kecuali makanan tersebut jelas dari hewan yang diharamkan (Zulaekah, dkk, 2005: 30).

Pentingnya pesan dakwah informatif mengenai makanan halal ini disampaikan kepada masyarakat atau mad'u dalam hal ini yaitu penonton agar mengetahui tentang pentingnya makanan halal dan berhati-hati dalam mengkonsumsi terutama untuk mereka yang tinggal di lingkungan dimana Islam adalah minoritas, selain karena kesehatan pentingnya makanan halal juga sudah diperintahkan Allah dalam Alquran.

\section{Pesan Dakwah Persuasif}

Pesan dakwah persuasif adalah pesan dakwah yang mana pesan tersebut bisa memberikan pengaruh kepada mad'u untuk menerima ajaran Islam dan mau merubah baik sikap maupun perilakunya. Persuasif sendiri dalam komunikasi ialah pesan-pesan yang disampaikan mempunyai pengaruh untuk merubah sikap perilaku dan kepercayaan komunikan atau penerimanya. Komunikasi persuasif dalam dakwah ialah komunikasi yang mana berfokus pada sisi psikologi mad'u yang bertujuan untuk membangkitkan kesadaran agar mau menerima dan mengamalkan ajaran Islam (Atabik, 2014: 128).

Ditemukan 13 pesan dakwah persuasif pada program muslim travelers NET. yang meliputi ajakan dan motivasi untuk menegakan syariat Islam, beribadah dan berdakwah.

Pertama pesan dakwah persuasif tentang ajakan dan motivasi untuk menegakan syariat Islam pada program muslim travelers NET. ada di episode Amerika Serikat, saat itu pembawa acara Firza Arifien bertemu dengan Jasmine Crawford di Union Square Manhattan, berikut contohnya:

"Sangat mencintai Islam/ ia pun mengubah panampilan sesuai syariat/ jasmine pun senan tiasa menegakkan ajaran Islam/ dalam kehidupannya sebagai muslim//" (09 Juni 2018, 04:50-05:00).

Bersamaan dengan kalimat diatas ditampilkan pula Jasmine yang menggunakan hijab, darisitu kita juga seakan diajak untuk mengamalkan ajaran Islam salah satunya untuk berpakaian sesuai syariat Islam terutama hijab untuk 
muslim perempuan. Ini sesuai dengan perintah Allah dalam Surat Al-Ahzab (33): 59 :

"Wahai Nabil Katakanlah kepada istri-istrimu, anak-anak perempuanmudan istri-istri orang mukmin, "Hendaklah mereka menutupkan jilbabnya ke seluruh tubuh mereka" yang demikian itu agar mereka lebih mudah untuk dikenali, sehingga mereka tidak diganggu. Dan

Allah maha pengampun, Maha penyayang” (Kemenag RI, 2006: 603).

Dalam tafsir Kementerian Agama RI ayat ini menjelaskan bahwa Allah telah memberikan perintahnya kepada muslim terutama istri-istri putri-putri Nabi, untuk mengulurkan jilbab ke seluruh tubuh mereka. Ini bertujuan agar mereka mudah dikenali melalui pakaiannya karena berbeda dengan budak perempuan. Sehingga orang lain tidak bisa mengganggu dan mengambil kesempatan. Perempuan yang berpakaian sopan akan terhindar dari orang-orang jahil dan sebaliknya perempuan yang berpakaian terbuka dan memperlihatkan auratnya mudah dituduh perempuan yang kurang baik. Bagi orang yang berubah dan menjadi lebih baik maka sesungguhnya Allah itu Maha Pengampun dan Pengasih.

Menutup aurat selalu identik dengan muslim perempuan tetapi sebenarnya menutup aurat tidak hanya dianjurkan untuk perempuan saja tetapi laki-laki juga harus menutup auratnya. Menutup aurat merupakan kewajiban untuk semua muslim baik laik-laki maupun perempuan terutama mereka yang telah dewasa dan dilarang memperlihatkan dengan sengaja dan tanpa ada alasan yang dibenarkan syariat (Baso, 2015: 188).

Pesan dakwah persuasif diatas memotivasi untuk menegakan syariat Islam salah satunya untuk menutup aurat yang mana itu merupakan kewajiban untuk seorang muslim tidak hanya perempuan namun laki-laki juga harus menutup auratnya. Selain kewajiban menutup aurat terutama mengenakan hijab untuk perempuan menjadi ciri dari seorang muslim.

Kedua pesan dakwah persuasif tentang beribadah pada program muslim travelers NET. ada pada episode Korea Selatan, (Gangnam), saat itu Shaza Belladona sebagai pembawa acara bertemu dengan Ayana Moon dan bertanyatanya seputar bagiamana Ia masuk Islam dan bagaimana setelahnya, berikut contohnya:

"... After I convert in Islam/ I believe in god/ I believe in Islam/ and then actually I wear hijab/ and many things just differented/ / Because actually believing God is really different/ whenever I have bad problem/ and bad situation/ I always pray for to Allah...//"

“... setelah saya masuk Islam/ saya percaya tuhan/ saya percaya Islam/ dan kemudian saya menggunakan hijab/ dan banyak hal yang berbeda// karena benar percaya kepada tuhan/ kapanpun saya memiliki permasalahan yang buruk/ dan dalam situasi yang buruk/ saya selalu berdoa kepada Allah//..." (18 Mei 2018, 09:30-09:58). 
Dari kalimat diatas kita diajak untuk percaya kepada Allah dan selalu berdoa kapanpun, terlebih jika sedang dalam permasalahan dan situasi yang buruk. Sama seperti firman Allah dalam Surat Al-Mu'min (40) : 60, yang artinya : 'Dan Tuhanmu berfirman "Berdoalah kepaku, niscahya akan aku perkenankan bagimu. Sesungguhnya orang-orang yang sombong tidak mau menyembah-Ku akan masuk neraka jahanam dalam keadaan hina dina" (Kemenag RI, 2007: 378).

Dalam tafsir Kementerian Agama RI ayat ini menjelaskan bahwa Allah memerintahkan agar manusia berdoa kepada-Nya. Jika mereka berdoa niscaya Allah akan memperkenankan doa itu. Doa sendiri ialah salah satu bentuk dari beribadah. Ayat ini juga merupakan peringatn dari allah kepada orang-orang yang tidak mau beribadah juga pernyataan Allah kepada hamba-hamba-Nya agar mendapatkan kebaikan dan kebahagiaan di dunia maupun di akhirat.

Pesan dakwah persuasif diatas perlu disampaikan untuk memotivasi agar selalu beribadah yaitu berdoa dalam keadaan apapun teruatama ketika dalam keadaan sulit.

Ketiga dakwah persuasif berdakwah pada program muslim travelers NET. ada pada episode Spanyol, saat itu pembawa cara Shaza Belladona berkesempatan untuk mengunjungi salah satu workshop seniman di Spanyol milik Munira seorang mualaf Amerika yang pindah ke Spanyol dan menjadi muslim wanita pertama yang menjadi pengusaha di Garanada pasca masuknya Islam di Andalusia, berikut contohnya:

"we a lot of dakwah/ to our work/ not only through the products we do/ but to the shop/ to the workshop/ because people come of all the time / " "

"kita banyak melakukan dakwah/ melalui karya kami/ tidak hanya melalui produk yang kami buat/ tapi melalui toko/ melalui seminar/ karena banyak orang berdatangan setiap saat//" (25 Mei 2018, 15:01-15:40).

Dari kalimat diatas kita diberikan kesadaran bahwasanya dakwah bisa dilakukan oleh siapapun melalui metode atau hal yang kita sukai dan kita kuasai, karena dakwah sendiri memiliki banyak metode dan media yang bisa digunakan, mengingat teknologi yang semakin canggih dan masyarakat yang lebih modern maka dakwahpun harus di sesuaikan.

Dakwah sudah menjadi kewajiban bagi seorang muslim, namun dakwah tidak hanya melalui ceramah saja, banyak media dan cara yang bisa dilakukan untuk berdakwah seperti melalui seni atau kerajianna tangan. Dalam seni ada yang disebut dengan ornament yaitu hiasan dalam arsitektur berupa dekorasi, pahatan, lukisan dan kerajinan tangan, yang mana dalam Islam ornamen bukan sekedar hiasan kosong melainkan memiliki fungsi sebagai pengingat tauhid, pola-pola indahnya bertujuan untuk mengingat dan menginternalisasi kehadiran Allah di dalam diri (Yahya, 2007: 224).

\section{Pesan Dakwah Hiburan}

Pesan dakwah hiburan adalah pesan dakwah yang isinya bisa membuat mad'u terhibur, senang dan merasa puas. Salah satu program televisi yang diminati 
masyarakat ialah program hiburan, maka tidak salah jika pesan dakwah disampaikan lewat program tersebut, bahkan alangkah baiknya jika hiburan bersumber dari nilai dan materi keagamaan agar tidak membuat orang jauh dari agama (El Ishaq, 2014: 127).

Ditemukan 3 pesan dakwah hiburan pada program muslim travelers NET. yang menampilkan kebudayaan, pemandangan alam dan karya seni pertama pesan dakwah hiburan yang menampilkan kebudayaan ada pada episode Korea Selatan (Gangnam), Shaza Belladona sebagai pembawa acara bertemu dengan Fathan Pranaya seorang WNI yang telah menyelesaikan studi magisternya di salah satu universitas di Seoul dan sekarang sedang bekerja di salah satu starup di Seoul menjadi Fotografer Travel, saat itu Shaza dan Fathan berkunjung ke festival bernama Bamdokkaebi Night Market untuk menyicip makanan-makanan yang ada disana, berikut contohnya:

"Fathan : oh iya/ tapi Sha/ makanan-makanan disini itu/ kita harus juga mikirin halal apa nggak/ soalnyakan kita cuma bisa makan-makanan yang halalkan disini/ jadi disini mungkin/ bisa ditanya ke penjualnya/ atau emang kalau bisa sedikit baca tulisan Korea/ bisa dilihat apakah mengandung babi/ atau nggak gitu// Shaza : apa itu bahasa koreanya/

Fathan : bahasa koreanya babi itu/ dwaeji, bisa nanya ke mas-masnya "dwaeji gogi isseoyo//" (18 Mei 2018, 18:16-18:45).

Kalimat diatas selain mengingatkan dan memberitahukan bahwa muslim hanya bisa makan makanan yang halal, kita juga sekaligus belajar bagaimana bahasa koreanya untuk menanyakan apakah makanan tersebut mengandung babi atau tidak, hal itu jelas membuat penonton senang karena mengingat halhal mengenai Korea sedang digemari oleh banyak orang.

Bahasa merupakan aspek kebudayaan yang bisa digunakan untuk mengekspresikan budaya kepada orang lain. Bahasa juga merupakan alat untuk merepresentasikan nilai-nilai budaya seperti keyakinan, sikap dan pandangan masyarakat (Arifin, 2018: 1).

Kedua pesan dakwah hiburan yang menampilkan pemandangan alam pada program muslim travelers NET. ada pada episode Korea Selatan (Islam di Korea Selatan), pembawa acara Shaza Belladona mengunjungi Jinhae Cherry Blossom Festival yang diadakan di Changwon, Seoul. Saat itu banyak warga yang juga sedang menikmati indahnya bunga sakura yang bermekaran juga aktraksi dan pameran yang ada di festival tersebut berikut contohnya:

"Masyaallah cantiknya/ ya tuhan kami/ tiadalah engkau menciptakan semua ini dengan sia-sia//" (05 Juni 2018, 04:46-04:53).

Bersamaan kalimat diatas, ditampilkan pula keindahan bunga sakura dan orang-orang yang sedang menikmatinya juga dilengkapai dengan surat Ali-Imran (3) 190-191:

"Sesungguhnya dalam penciptaan langit dan bumi, dan silih bergantinya malam dan siang terdapat tanda-tanda (kebesaran Allah) bagi orang yang berakal (190) (yaitu) orang-orang yang mengingat Allah sambil berdiri atau 
duduk atau dalam keadan berbaring dan mereka memikirkan tentang penciptaan langit dan bumi (seraya berkata): "Ya Tuhan kami, tiadalah Engkau menciptakan ini dengan sia-sia, Maha Suci Engkau, lindungilah kami dari azab neraka (191)" (Kemenag RI, 2006: 96).

Dari kalimat dan ayat quran diatas kita tahu bahwasanya traveling atau sesuatu yang membuat kita senang dan terhibur juga bisa menjadi sesuatu yang harus kita syukuri, jalan-jalan sekaligus bertadabur dan bertafakur atas ciptaan Allah Swt.

Ketiga pesan dakwah hiburan karya seni pada program muslim travelers NET. ada pada episode Spanyol, saat itu pembawa acara Chiki Fawzi mengunjungi salah satu seniman Spanyol yaitu Ihsan Rajjaq, yang mana Ihsan adalah seniman muslim yang ingin mengenalkan Islam lewat seni yaitu perhiasan dengan kaligrafi didalamnya, berikut contohnya:

"Tinggal di negeri dimana Islam pernah jaya/kini warga muslim tengah berupaya menegakkan kembali kebesaran ini/ lewat berbagai cara/termasuk seni/sebagai media untuk menyiarkan indah dan teduhnya Islam// (25 Mei 2018, 13:34-13:50).

Narasi diatas menunjukan tentang bagaimana Islam ditunjukan lewat karya seni yaitu perhiasan untuk dilihat dan diakui oleh orang lain bahwasanya Islam itu ada dan indah. Seperti yang dilakukan Ihsan seorang seniman di Spanyol ia membuat perhiasan dengan kaligrafi sebagai pelengkapnya untuk mengenalkan keindahan Islam. Beberapa seni yang lahir dalam ajaran Islam ialah seni arsitektur (masjid) dan seni tulisan (Kaligrafi) yang mana Islam membolehkan karya seni selama itu tidak menyimpang (Rizali, 2012: 2).

Dakwah melalui seni bukan sesuatu yang baru karena dulu juga walisongo berdakwah melalui seni, salah satu seni yang bisa dijadikan media dakwah ialah kaligrafi. Kaligrafi menurut bahasa ialah tulisan indah. Dalam Islam perkembangan kaligrafi sangatlah pesat, dengan memperindah tulisan Arab merupakan bentuk rasa cinta terhadap Alquran. Dalam seni menulis kaligrafi mencakup bagaimana menyusun huruf yang indah untuk dipandang, yang dipelajari melalui ilmu tipografi (Ahmad, 2013: 79).

\section{PENUTUP}

Setelah melakukan analisis isi pesan dakwah pada program muslim travelers NET. yang tayang pada tahun 2018 dengan mengambil episode Amerika Serikat satu episode, Korea Selatan tiga episode, dan Spanyol satu episode yang mana terlebih dahulu telah melewati tahap coding, berikut kesimpulan yang bisa diambil :

Pesan dakwah informatif yang terdapat pada program muslim travelers NET. banyak menjelaskan tentang sejarah masuk dan berkembanganya Islam baik di Korea Selatan, Amerika dan juga Spanyol, lalu mengenai syiar Islam yang dilakukan warga muslim baik lokal maupun warga negara asing di negara-negara 
tersebut, dan terakhir yaitu informasi tentang tempat-tempat yang menyediakan makanan halal.

Pesan dakwah persuasif yang ada pada program muslim travelers NET. ialah, ajakan untuk mau mengamalkan dan menerapkan syariat Islam dalam kehidupan sehari-hari seperti menggunakan hijab untuk muslim perempuan, selalu beribadah kepada Allah baik dimanapun kapanpun dan dalam keadaan apapun, dan juga memotivasi untuk berdakwah dengan media atau metode kita kuasai bahkan bisa melalui karya seni.

Pesan dakwah hiburan yang terdapat pada program muslim travelers NET. ialah tayangan yang menampilkan pemandangan dan karya seni yang indah, juga belajar bahasa aisng untuk keperluan seperti halnya syiar atau contoh kecilnya untuk menanyakan apakah makanan itu halal atau tidak.

Dari tiga kategori pesan yang ada pada program muslim travelers NET. pesan dakwah yang mendominasi ialah pesan dakwah informatif.

Adapun saran Untuk peneliti selanjutnya, diharapkan bisa mengkaji lebih dalam lagi mengenai pesan dakwah pada program televisi baik dari segi kategori pesannya atau pengaruh tayangan bahkan bisa juga respon masyarakat terhadap suatu program televisi.

\section{DAFTAR PUSTAKA}

Afdjani, H. (2014). Ilmu Komunikasi Proses Dan Strategi. Tangerang: Indigo Media. Ahmad, A. A. (2013). Dakwah, Seni dan Teknologi Pembelajaran. Jurnal Dakwah Tabligh, 14(1), 75-89.

Aliyudin, dan Enjang AS. (2009). Dasar-Dasar Ilmu Dakwah. Bandung: Widya Padjadjaran.

Amin, S. M. (2013). Ilmu Dakwah. Jakarta: Amzah.

Arifin, M.N. (2018). Hubungan Budaya Dan Pengajaran Bahasa. Diakses tanggal 08

November

https://www.researchgate.net/publication/328052056_HUBUNGAN_

BUDAYA_DAN_PENGAJARAN_BAHASA.

Atabik, A. (2013). Prospek Dakwah Melalui Media Televisi. At-Tabsyir Jurnal Komunikasi Penyiaran Islam, 1(2), 191-209.

Atabik, A. (2014). Konsep Komunikasi Dakwah Persuasif Dalam Perspektif Alquran. At-Tabsyir Jurnal Komunikasi Penyiaran Islam, 2(2), 117-136.

Aziz, M. A. (2009). Ilmu Dakwah. Jakarta: Kencana Predana Media Group.

Badaruddin. (2013). Dakwah Informatif dan Transformatif Penyuluh Agama. Jurnal Ilmu Dakwah dan Pengembangan Komunitas, VIII(01), 52-68.

Basit, A. (2013). Dakwah Cerdas Era Modern. Jurnal Komunikasi Islam, 03(01), 76-93.

Baso, M. (2015). Aurat dan Busana. Jurnal Al-Qadau. 2(2), 186-195.

Basri, M. (2014). Drikir dan Do’a Rasulullah. Surakarta: Biladi. 
Dulwahab, E. (2016). Rebranding Dakwah di Media Televisi. Jurnal Aktualisasi Nuansa Ilmu Dakwah, 15(2), 299-316.

El Ishaq, R. (2013). Dakwah Di Tengah Industrialisasi Media. Jurnal Komunikasi Islam, 03(01), 137-151.

El Ishaq, R. (2014). Hiburan dan Dakwah : Sebuah Era Baru dakwah Islamiyah. At-Tabsyir Jurnal Komunikasi Penyiaran Islam, 2(1), 117-132.

El Ishaq, R. (2016). Pengantar Ilmu Dakwah. Malang: Madani.

Farihah, I. (2013). Media Dakwah Pop. At-Tabsyir Jurnal komunikasi Penyiaran Islam,1(2), 25-45.

Fatoni, U dan Enjang T. (2017). Dakwah Literasi Ustadz Giovani Van Rega: Analisis Imbauan Pesan Dakwah. Jurnal Komunikasi Islam, 7(2), 209-225.

Japarudin. (2012). Media Massa dan Dakwah. Jurnal Dakwah. VIII(1), 1-15.

Kementerian Agama RI. (2006). Alquran dan Terjemah. Surabaya: Karya Agung Surabaya.

Kementrian Agama RI. (2007). Alquran dan Terjemah. Bandung: Sinar Baru Algesindo Offset.

Munir, M., dan Ilaihi W. (2009). Manajemen Dakwah. Jakarta: Kencana Prenada Media Group.

Rizali, N. (2012). Kedudukan Seni Dalam Islam. Tsaqafa: Jurnal Kä̈an Seni Budaya Islam, 1(1), 1-9.

Rustandi, R. (2018). Analisis Wacana Kritis Komodifikasi Daí Dalam Program Televisi. Communicatus: Jurnal Ilmu komunikasi, 2(2), 197-222.

Saputra, W. (2012). Pengantar Ilmu Dakwah. Jakarta: PT RajaGrafindo Persada.

Vera, N. (2016). Komunikasi Massa. Bogor: Ghalia Indonesia.

Yahya, M. W. (2007). Strategi Dakwah Islam Dalam Pengembangan Seni dan Peradaban. Mediator, 8(2), 221-226.

Yolanda, Y. (2017). Sastra Bermuatan Dakwah dan Perkembangannya di Indonesia. Prosiding Seminar Nasional Bahasa dan Sastra. (455-461) Universitas Negeri Malang.

Zahrah, A. (1994). Dakwah Islamiah. Bandung: PT Remaja Rosdakarya

Zaini, A. (2015). Dakwah Melalui Televisi. At- Tabsyir Jurnal Komunikasi Penyiaran Islam, 3(1), 1-20.

Zaini, A. (2017). Retorika Dakwah Mamah Dedeh dalam Acara "Mamah \& Aa Beraksi" di Indosiar. Ilmu Dakwah: Academic Journal for Homiletic Studies, 11(2), 219-234.

Zulaekah, S dan Kusumawati, Y. (2005). Halal dan Haram Makanan Dalam Islam. Subuf, XVII(1), 25-37.

Zulkarnaini, Z. (2015). Dakwah Islam di Era Modern. Jurnal Dakwah Risalah, 26(3), 151-158. 
M. D. Wijaya, S. Sumijaty, U. Fatoni 